\title{
Determinants and Sustainability of Manufacturing Sector Performance in Nigeria: The Roles of Selected Macroeconomic Variables
}

\author{
Falade Abidemi Olufemi Olusegun \\ Correspondence: Falade Abidemi Olufemi Olusegun, Senate Research Consulting Firm, Nigeria. \\ Received: July 12, 2021 \\ doi:10.11114/afa.v7i2.5302 \\ Accepted: July 14, 2021 \\ Available online: July 22, 2021 \\ URL: https://doi.org/10.11114/afa.v7i2.5302
}

\begin{abstract}
Manufacturing sector is a vibrant sector that spurs growth in every other sector of the economy. Despite this, macroeconomic environment in the country has not made this desire materialized. Therefore, the study examined the determinants and sustainability of manufacturing sector performance in Nigeria from 1994-2019. The data used include manufacturing sector output, interest rate, real exchange rate, tax rate, money supply and trade openness. Also, Error Correction Model (ECM) and Pairwise Granger Causality(PGC) techniques were used for the formulated objective. The unit root test confirmed stationarity of interest rate at level; while other were integrated of order one $(\Delta=1)$. The Johansen co-integration established a long-run relationships. The ECM corrected the disequilibrium at an annual rate of $77.5 \%$. Also, real exchange rate, tax rate and trade openness had a direct and significant effect on manufacturing sector output. While, interest rate and money supply were non-significance. The PGC result revealed a bi-directional causality between real exchange rate and manufacturing sector and tax rate and manufacturing sector output. It was concluded that increase in consumption tax, real exchange rate and liberation of the economy were the determinants of manufacturing sector performance, while appreciation of nigeria's currency (naira) and increase in tax rate with proportional improvement in infrastructural facilities are needed to sustain it. Therefore, recommended that the financial institutions especially the apex bank should eliminate different bench-mark of exchange rate policy by allowing the market force of demand and supply to depict the real value of naira.
\end{abstract}

Keywords: Manufacturing sector performance, money supply, trade openness, Error Correction Model (ECM)

\section{Introduction}

Manufacturing Sector (MS) in both the developed and developing economies is essential for growth and development in the sense that the sector is responsible for transformation of crude materials into finished goods. The developed economies around the world know the significant importance of this sector, therefore, always putting in place every machineries and human resources to sustain and achieve maximum productivity in this sector. However, reverse is the case in developing countries like Nigeria where most of them concentrate more on primary production. In achieving industrialization especially in an emerging economy like Nigeria, Odiora (2013) suggests that government at all level must ensure that they continue to provide the enabling environment for private sector with formulation of good policies that encourage innovators. One common attribute of manufacturing process is that it transforms raw or unfinished goods to finished goods through the addition of utility to such goods at different stages of production before reaching final consumer (Falade, 2021). In achieving this desire, manufacturing sector considers both internal and external factors in decisions making process. Among the internal factor include capital mix, financial resources, loan, materials, etc., while, external factors are outside the domain of business organization. Among the external factor is macroeconomic factors. Macroeconomic factors are factors affecting an organization in which its management has no control over it, this include political conditions, government regulations and policies, etc. (Egbunike \& Okerekeoti, 2018).

Also, it must be noted that both internal and external factors are considered when measuring or ascertaining manufacturing performance. In view of this, Peace (2019) remarks that the interaction of these internal factors and macroeconomic variables is what determines the performance of a firm. This could be attributed to the fact that macroeconomic indices set the pace of how well a firm will thrive. The macroeconomic environment is determined by policies and macroeconomic variables. A stable macroeconomic environment favours economic growth by reducing uncertainty (Olorunfemi, Tomola, Felix, Ogunleye, 2013). These macroeconomic variables highlighted in the literature refer to economic-wide variables such as interest rate, rate of inflation, foreign exchange, trade openness, foreign direct 
investments, budget deficits, macroeconomic instability, fiscal policy such as tax and so on. The performance of manufacturing firms can therefore, be linked to variations in the aforementioned variables.

The MS is a vibrant sector that spur growth in every other sectors of the economy. For instance, the creation of a manufacturing firm in a particular environment increases demand for raw material, labour, infrastructural facilities, etc., within the area. In Nigeria's setting, the efforts towards spurring industrialization by increasing the output of manufacturing firms has proved abortive. The output of manufacturing sector and its contribution to GDP remains quite insignificant compared to what it ought to be. The reason behind the still shaky nature of the manufacturing sector in Nigeria can be linked to the variations of economic wide variables over time (Egbunike \& Okerekeoti, 2018). The irregular nature of business activities in the country around '70s and '80s necessitated the need for economic reforms both in policy and institutions. This erratic trend was caused by substantial windfall revenues gained from increases in oil prices and the subsequent fall in oil prices.

The determinants of manufacturing firms and the manufacturing sector at large is therefore, considered critical in the process of industrialization and as such, governments over the years have made attempts at mitigating the unfavorable business environment currently prevalent. It is argued that the fastest channel through which an economy can be transformed from having a predominantly traditional sector to a modern sector is via increasing industrial capacity and technological innovation (Peace, 2019). Also, the interaction of macroeconomic indices and the ability to sustain such improvement have a long impact on manufacturing output due to time lag. For instance, the persistent nature of general price level reduces purchasing power of individual or household and this moves down into capacity underutilization. Considering the case of the sector access to credit, the inability to acquire credit hampers the ability to procure goods and services. In view of this, Odiora (2013) attributes the low productivity of the sector to the increased cost of production caused by high cost, high interest rate, poor demand, insufficient raw material supply and inadequate working capital. Other factors that have affected the state of the manufacturing sector includes the epileptic supply of electricity and the increased pump price used mainly in the private production of power (Rafiq, 2018).

Also, sustainability of manufacturing sector performance lies in the ability to maintain the obtained improvement in productivity overtime. Nigeria is a mono-economy with major source of revenue coming through oil and gas sector, therefore, sustainability also entails the sector to provides huge revenue to government's coffer. The feat of sustainability of manufacturing sector performance has not be fully achieved in Nigeria, since available evidences have shown that the improvement recorded in the sector has reduces so far. For instance, the manufacturing sector performance index has declined from 70.1\% in 1980 to 57.45 in June 2019 (Trading Economics, 2019). The discovery of oil in large quantity affected this sector, therefore, reduced productivity in the sector. For instance, it was discovered that year 2000 was the era the country started experiencing a real decline in manufacturing with oil revenue stood at $1,591.68$ billion naira; while, that of manufacturing performance was $\$ 826.03$ billion naira. Thus, implies that increase in oil revenue in that year was greater than manufacturing out by $65.8 \%$ (Falade, 2021). The attempt to extenuate the near collapse of the economy during the fall in price of crude oil necessitated economic reforms. These economic reforms included the deregulation of the foreign exchange market, abolition of import licenses, and the devaluation of the naira. These reforms however did not cause the desired change. There were slow implementation of policies as well as prolonged fiscal indiscipline. Given this, this study examines the sustainability of manufacturing sector performance in Nigeria using some selected macroeconomic variables from 1994-2019. The selection of 1994 as the base year was as a result of introduction of Value Added Tax in Nigeria in 1994 as well as availability of data to 2019 from CBN, Statistical Bulletin (2019)

\subsection{Statement of the Problem}

The manufacturing sector is an energetic sector for economic growth for developing nations worldwide, Nigeria inclusive. As such, a country with the intent to expand its economy must do well to ensure that it creates a macroeconomic environment that will aid manufacturing firms to thrive successfully. However, in Nigeria's situation opposite is the case. Peace (2019) attributes this to the policies made in the past which had several negative effects on the sector. These effects can be seen in how Grif, a manufacturing firm previously existing in Nigeria exited on account of how it was unable to get annealed cold-rolled steel which was its key raw material. According to the Manufacturers Association of Nigeria (MAN) in 2018, the recession that ended in 2017 claimed at least 50 manufacturers, mainly SMEs. The problem according to the association was caused by poor access to foreign exchange to import inputs. In 2019 of Doing Business Report, the World Bank ranks Nigeria as 146th, out of 190 countries on the ease of doing business index globally and 22nd in sub-Saharan Africa (MAN, 2018). Despite this. issues such as absence of tax incentives, poor infrastructure, corruption and bureaucracy has created an unfriendly business environment for investors. In July 2018, a foremost firm in the diaper production industry called Procter \& Gamble shut down its \$300-million-dollar plant in Agbara, Lagos. This was allegedly due to the issues relating to inability to meet projected 
targets due to unfriendly tax impositions as well as harsh treatments from the Customs Service which replaces its function as a business facilitator to one of a revenue earner.

Also, there is fall in demand for domestic goods, causing further depreciation in domestic currency. All of this combines to make exports competitive. However, as a result of liquidity squeeze in the economy, manufacturing industries would be unable to find investors needed to cater for the opening to export more products. This combines with the unattractively high interest rate and credit inaccessibility to further amplify the condemnable unbecoming state of the macroeconomic environment. An evidence of the poor performance of the sector can be seen in the somewhat insignificant contribution of the sector to GDP. Having an all-time high of $26.22 \%$ in 1985 over the past 35 years and its lowest point sitting at $-30.93 \%$ in 1983, currently is $9.20 \%$ ( (World Bank and 2016). These situations require urgency in consideration. Thus, necessitates a gap for this present study to examine its determinants and sustainability in Nigeria from 1994-2019. This is necessary in order for Nigeria's government to be able to make policy reviews and identify the core macroeconomic indicators and manipulation of its values to check the continuous downturn in the manufacturing sector and pilot it in the right direction as the integral part of industrialization.

\subsection{Objective of the Study}

The study intends to sought out the following objectives;

i. to examine the macroeconomic determinants of manufacturing sector performance in Nigeria.

ii. to identify factors responsible for sustainability of manufacturing sector performance in Nigeria.

\section{Literature Review}

\subsection{Manufacturing and Overview of its Performance in Nigeria}

Manufacturing is concerned with the addition of utility or value to raw materials. The core function of manufacturing sector is to add value to good and transform such to finished goods. According to Nwanne (2015), manufacturing sector is concerned with the developing and processing of raw material and indulge or give free rein in either the creation of new commodities or in value addition. One major reason for this is the nature of the activities the sector undertake that has a link across every sector of the economy (Odiora, 2013). The industry needs funds from external and internal sources to expand its market operation. The external funds are adjudged to contribute great to the manufacturing industry because of the implication of such foreign currency on local currency. In view of this, Falade, Aladejana and Alabi, (2020) reveal that Nigeria's financial system is characterized with the local financial markets that lack sufficient funds to stimulate economic growth and development. Also, Babatunde et al., (2011) show that the Nigeria's financial sector that is part of financial development is characterized with a shortage of funds, therefore, reduce their credit to the private sector. The diagram below reveals the true performance of manufacturing sector in the country from 1981-20019.

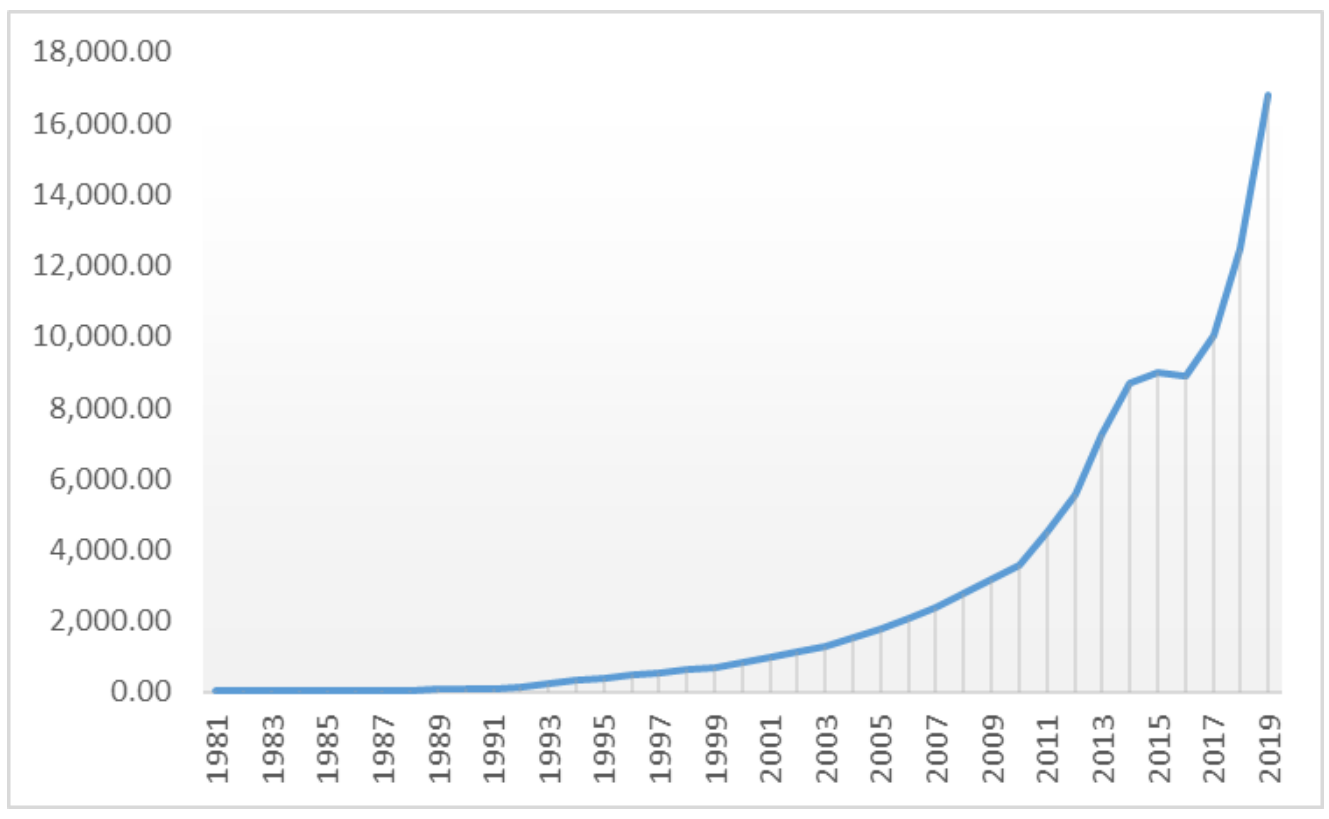

Figure 1. Trend and Pattern of Manufacturing Performance in Nigeria

Source: Researcher's Compilation from Excel (2021) 
The figure 1 above shows the trend analysis of Nigeria's manufacturing sector performance from 1981- 2019. Nigeria's manufacturing sector output starts on a good note in 1981 with aggregate output of 26.89 billion naira. From 1982-1990, it increased by an additional 400.14 billion naira within nine years. This increase may be attributed to adoption of Structural Adjustment Programme, liberation of the economy and price controls and regulations. The graph shows that between 1991-2001, manufacturing sector performance in the country was encouraging with each operating within hundred and thousand units. Also, from 2002-2016, it was within a thousand unit with a value of 8,903.24 billion naira in 2016. Ever since 2016, it has been on an increasing rate.

\subsection{Empirical Studies}

Achi (2020) studied macroeconomic and manufacturing sector performance in Nigeria. The study showed real- GDP, exchange rate, foreign direct investment, inflation rate directly contributed to manufacturing sector performance in the country; while, interest rate drastically reduced it. A study on financial institutional and manufacturing performance in Nigeria by Ogunleye and Saliu (2013) using ECM from 1970 - 2005 confirmed that financial institutions reforms had no significant influence on manufacturing sector performance in the country. A similar study by Charles (2012) showed that monetary supply had a direct and significant effect on manufacturing index performance; while, inflation rate lending rate, income tax rate and exchange rate was significant with an inverse association with it.

Vector Error Correction Model was used by Obamuyi, Edun and Kayode (2012) to determine the link between bank lending, economic growth and manufacturing sector in Nigeria. The result established that bank lending rates and manufacturing capacity utilization were directly related to manufacturing output in Nigeria. The study concluded that the growth of manufacturing output has not been enough to generate sizeable growth in economy. Also, a study from 1980-2012 using OLS by Horgan (2014) confirmed that interest rate did not influence manufacturing output; while government expenditure had a direct effect on it. Also, from 1975-2011 using ECM Odiora (2013) discovered a long term equilibrium existed among the variable. Also, credit to the manufacturing and advance sharply increase manufacturing output in Nigeria.

Using Cochrane-orcutt method Ebere and lorember (2016) study the contribution of commercial bank credit to manufacturing sector output between 1980-2015 in Nigeria. The result revealed that both the inflation rate and interest rate were indirectly related manufacturing sector output; while, broad money supply showed a significant and direct sign on manufacturing sector performance in Nigeria. A similar study by Ogar et al. (2014) Using OLS from 1999 2011 confirmed that bank credit and interest rate had no effect on output of the manufacturing sector. Also, Olayemi and Michael (2016) using a VAR analysis from 1986 - 2013, it was discovered that lending rate was directly related to industrial output. A study in Pakistan's textile industry by Zulfiqar and Din (2015) using a panel of 50 textiles firms for the period 2006 to 2011, the study established that interest rate was a direct determinant factor on return on equity. Study by Gideon et. al. (2015) using ECM from 1970 -2011 in Nigeria showed that banks' lending rate, exchange rate and the real rate of interest were determinants that exerted a direct and significant effect on manufacturing sector; while, financial deepening couple with interest rate had a significant and negative effect on it in Nigeria.

A study by Akpan., Yilkudi, and Opiah, (2016) using a VECM and annual data from 1981-2014 affirmed high lending indirectly influence manufacturing output in the long-run. This suggests that increase in lending rate undermines manufacturing output, thus retarding growth in the real sector. Also, Erinma (2016) using data from 1981 to 2015 and OLS, it was discovered that interest rate in Nigeria has a negative effect on the contribution of the manufacturing sector to GDP as well as on the average capacity utilization of the Nigeria manufacturing sector. Tams, et al (2018) using ECM confirmed that exchange rate had non-significant and positive long-run effect on manufacturing industry output.

\section{Methods}

\subsection{Theoretical Framework}

Keynesian theory of investment is adopted as the theoretical framework. The theory was propounded by Keynes (1937), the theory avows that investment is a direct function of interest rate. Implying that decrease in interest rate stimulate investment in the real sector of the economy. As assumes in the theory, interest is always and every time a monetary phenomenon. Onakoya (2014) remarks that a well-functioning and thriving manufacturing sector is a necessity and an integral part of the industrialization process for developing countries. This indicates that manufacturing sector performance is a subset of sustainable development through the process of spurring other sectors of the economy including the service sector. As part of the national accounts of a country and in regard to the national income equation, the equation of the theory is depicted below as follow:

$$
Y=C+I+G
$$

Where; $\mathrm{Y}=$ National output, $\mathrm{C}=$ consumption, $\mathrm{I}=$ investment and $\mathrm{G}=$ Government. In the above equation (i) investment (I) is a function of interest rate 


$$
I=f(i)
$$

Where $I$ represents investment in the manufacturing industry and $i$ is the interest rate.

The model for this study was built on Tams et al. (2018) model. The baseline model of Tams et al. (2018) is given below in linear form;

$$
I N D=f(E X R T, I N F L, M P R, M 2, F D I, M C A P \ldots \ldots(\text { iii })
$$

Where: $\mathrm{IND}=$ Manufacturing Industry output, INFL $=$ Inflation, $\mathrm{MPR}=$ Monetary policy interest rate, EXRT = Exchange rate, $\mathrm{FDI}=$ Foreign direct investment, $\mathrm{M} 2=$ Broad money supply and MCAP $=\quad$ Market capitalization.

The modified model of Tams et al. (2018) for this study is represented below:

$$
M A N O=f(I N T, R E E R, T A X, M S(3), O P E N) .
$$

Where; $\mathrm{MANO}=$ Manufacturing sector output (proxy as manufacturing sector performance), INT $=$ Interest rate, $\mathrm{REER}=$ Real Exchange Rate, TAX = Tax rate (proxy as Value Added Tax), MS(3)= Money supply and OPEN $=$ Trade Openness The linear form of equation (iv) becomes;

$$
M A N O=\alpha_{o}+\alpha_{1} I N T+\alpha_{2} R E E R+\alpha_{3} T A X+\alpha_{4} M S(3)+\alpha_{5} O P E N+\infty
$$

Putting equation $\mathrm{v}$ in error correction model approach format, we have;

$$
\triangle M A N O=\alpha_{6}+\alpha \delta_{7} \Delta I N T+\alpha_{8} \Delta R E E R+\alpha_{9} \Delta T A X+\alpha_{10} \Delta M S(3)+\alpha_{11} \Delta O P E N+E C M(t-1)+\mu \ldots \ldots .(v i)
$$

Where; $\Delta$ indicates first difference of each of the identified variables in the model, $\operatorname{ECM}(t-1$ is the short-run coefficient The related a priori expectations are: $\alpha_{7}<0, \alpha_{8}<0, \alpha_{9}>0, \alpha_{10}>0, \& 0>\delta_{11}<0$

Justification of the Variables in the Model: Real exchange rate, tax rate and money supply were included in the model to achieve the stated objectives. Also, they are the selected macroeconomic variables; while, interest rate and trade openness were included in the model because of the theory adopted by this study.

Table 1. Measurement and Source of Data

\begin{tabular}{lll}
\hline Variable & Measurement & Source \\
\hline MANO & $\begin{array}{l}\text { The sum of total output produced by manufacturing industries in Nigeria } \\
\text { divided by GDP in \% }\end{array}$ & CBN Statistical Bulletin 2019 \\
& \\
INT & Lending interest rate adjusted for inflation. & CBN Statistical Bulletin 2019 \\
REER & Nominal exchange rate multiply by domestic price (N)/foreign price (\$) & CBN Statistical Bulletin 2019 \\
TAX & Value added tax & CBN Statistical Bulletin 2019 \\
MS(3) & $\begin{array}{l}\text { M }_{3} / \text { GDP in } \% \\
\text { OPEN } \\
\text { The sum of imports and exports of goods and services divided by GDP in } \\
\text { constant prices }\end{array}$ & CBN Statistical Bulletin 2019 \\
\hline
\end{tabular}

Source: Researcher's compilation (2021)

\section{Results and Discussion}

Table 2. Correlation Matrix

\begin{tabular}{lllllll}
\hline Variable & MANO & INT & REER & TAX & MS(3) & OPEN \\
\hline MANO & 1.000000 & & & & & \\
INT & -0.172433 & 0.281282 & & & \\
& 0.2128 & & & & \\
REER & 0.348071 & 0.469479 & 0.854846 & & \\
& 0.0000 & 0.1327 & & & \\
TAX & 0.642855 & 0.697313 & 0.135111 & 0.287604 & & \\
& 0.0000 & 0.2274 & 0.0000 & & & \\
MS(3) & 0.183011 & 0.218288 & 0.403760 & 0.816395 & 0.284285 & \\
& 0.0000 & 0.2294 & 0.0000 & 0.0000 & & \\
OPEN & 0.378830 & 0.319580 & 0.766432 & 0.124630 & 0.392424 & 0.125296 \\
& 0.0000 & 0.4057 & 0.0000 & 0.0003 & 0.0003 & \\
\hline
\end{tabular}

Source: Researcher's Compilation from E-view-9 (2021)

In the above table 2, the result of manufacturing sector output was consistence with the Pearson's correlation assumption which confirms that a perfect strong correlation must exist when a variable (say, Xi) is estimated against 
itself (say Xi). The implication of this finding is that improvement that occurred in manufacturing sector performance was completely (100\%) influence by itself.

For interest rate and manufacturing sector output, a negative relationship was established between the duo with the coefficient value of $17.2 \%$ and $p$-value greater than 0.5 and 0.1 conventional level. This shows that indeed increase in lending interest rate had an infinitesimal influence on manufacturing sector output. The implication of this finding is that $17.2 \%$ reduction that occurred in manufacturing sector performance could not be attributed to increase in interest rate on borrowed loan alone.

The relationship between real exchange rate and manufacturing sector output was positive, with a moderate coefficient value of $34.8 \%$ and $p$-value less than 0.005 . This therefore, shows that a positive relationship occurred between the duo with real exchange rate having moderate effect on manufacturing sector output. The inference of this finding is that increase in naira compare with a dollar in term of the relative trade balance improve manufacturing performance.

The coefficient value of the degree of association between tax rate and manufacturing sector output was high with a value approximately to $64.3 \%$ and $p$-value less than 0.05 . This therefore, shows that a direct relationship occurred between the duo with tax having strong effect on it. The implication of this finding is that when increase in value of consumption tax increased manufacturing performance improved by $64.3 \%$.

Also, estimated value of money supply showed a direct association with manufacturing sector output and significant with $p$-value less than 5\%. Implying that quantity of money in circulation and bank deposit directly improved manufacturing performance

Furthermore, the estimated value of trade openness showed a positive degree association on manufacturing sector output with an estimated value of $37.9 \%$ and significant at $5 \%$ level. This implies that liberation of the economy through removing trade barrier, allowing inflow of foreign currency and good influenced manufacturing sector performance.

Table 3. Results of Unit Root Test

\begin{tabular}{lllllllll}
\hline \multicolumn{2}{l}{ Augmented Dickey Fuller (ADF) } & \multicolumn{7}{l}{ Phillip Perron (PP) } \\
\hline Variable & Test Statistic & $5 \%$ critical value & Level & S/NS & Test Statistic & $5 \%$ critical value & Level & S/NS \\
\hline MANO & $13.329618 /$ & $/ 2.991878 /$ & $\mathrm{I}(1)$ & $\mathrm{S}$ & $13.919855 /$ & $/ 2.991878 /$ & $\mathrm{I}(1)$ & $\mathrm{S}$ \\
$\mathrm{INT}$ & $/ 4.881566 /$ & $/ 2.986225 /$ & $\mathrm{I}(0)$ & $\mathrm{S}$ & $15.028277 /$ & $12.986225 /$ & $\mathrm{I}(0)$ & $\mathrm{S}$ \\
$\mathrm{REER}$ & $/ 3.966977 /$ & $/ 2.991878 /$ & $\mathrm{I}(1)$ & $\mathrm{S}$ & $13.966977 /$ & $/ 2.991878 /$ & $\mathrm{I}(1)$ & $\mathrm{S}$ \\
$\mathrm{TAX}$ & $/ 3.212483 /$ & $/ 2.991878 /$ & $\mathrm{I}(1)$ & $\mathrm{S}$ & $12.779017 /$ & $/ 2.991878 /$ & $\mathrm{I}(1)$ & $\mathrm{S}$ \\
MS(3) & $/ 4.767551 /$ & $/ 2.991878 /$ & $\mathrm{I}(1)$ & $\mathrm{S}$ & $14.924493 /$ & $/ 2.991878 /$ & $\mathrm{I}(1)$ & $\mathrm{S}$ \\
OPEN & $/ 4.529575 /$ & $/ 2.991878 /$ & $1(1)$ & $\mathrm{S}$ & $14.811412 /$ & $/ 2.991878 /$ & $\mathrm{I}(1)$ & $\mathrm{S}$ \\
\hline
\end{tabular}

Where; S indicates Stationary; NS non Stationary

Source: Researcher's Compilation from E-view-9

The estimated result of unit root test for ADF and PP confirmed that only interest rate was integrated of order zero. i.e. at zero level, there was absence of unit root problem in interest rate. Therefore, became independent of itself provided all identified variables are constant. While, manufacturing sector output, real exchange rate, tax rate money supply and trade openness were integrated of order 1.

Table 4. Johansen Co-Integration Test

\begin{tabular}{llllllll}
\hline \multicolumn{2}{l}{ Trace Statistics } & \multicolumn{7}{l}{ Max-Eingen Statistics } \\
\hline$H_{0}$ & $\begin{array}{l}\text { Trace } \\
\text { Statistics }\end{array}$ & $\begin{array}{l}\text { Critical value } \\
\text { 5\% level }\end{array}$ & at & Prob. & $\begin{array}{l}\text { Max-Eingen } \\
\text { Statistics }\end{array}$ & $\begin{array}{l}\text { Critical value } \\
\text { level }\end{array}$ & at \\
\hline $\mathrm{r}=0$ & 171.7843 & 95.75366 & $0.0000^{*}$ & 56.31018 & 40.07757 & Prob. \\
$\mathrm{r}=1$ & 115.4741 & 69.81889 & $0.0000^{*}$ & 44.89609 & 33.87687 & $0.0003^{*}$ \\
$\mathrm{r}=2$ & 70.57806 & 47.85613 & $0.0001^{*}$ & 37.19297 & 27.58434 & $0.0017^{*}$ \\
$\mathrm{r}=3$ & 33.38509 & 29.79707 & $0.0185^{*}$ & 20.88042 & 21.13162 & $0.0022^{*}$ \\
$\mathrm{r}=4$ & 12.50467 & 15.49471 & 0.1343 & 11.28146 & 14.26460 & 0.0542 \\
$\mathrm{r}=5$ & 1.223210 & 3.841466 & 0.2687 & 1.223210 & 3.841466 & 0.1407 \\
\hline
\end{tabular}

** indicate rejection of null hypothesis at the 0.05 level

Source: Researcher's Compilation from E-view-9 (2021)

As indicated in Table 4 above, the t-statistics associated with the Trace statistics were greater than critical values at zero relation $(\mathrm{r}=\mathrm{o})$ to fourth relationship $(\mathrm{r}=4)$. Therefore, established the fact that indeed long-run association existed between the identified variables; while that of Max-Eingen statistics showed three level of co-integrations. The implication of this result was that not only in the short-run changes in any one of the variables directly influence others, but also does in the long-run. 
Table 5. Error Correction Model

\begin{tabular}{|c|c|c|c|c|}
\hline \multicolumn{5}{|c|}{ R-squared=0.649250; Adjusted R-squared = 0.532334; F-statistic $=5.553108 ;$ Prob(F-statistic $)=0.002074$} \\
\hline Variable & Coefficient & Std. Error & t-Statistic & Prob. \\
\hline $\mathrm{ECM}(-1)$ & -0.774676 & 0.166433 & -4.654572 & $0.0002 * *$ \\
\hline$\Delta(\mathrm{INT})$ & -0.122204 & -0.416361 & 0.293505 & 0.7725 \\
\hline$\Delta($ REER) & 0.149076 & 0.050393 & 2.958267 & $0.0084 * *$ \\
\hline$\Delta(\mathrm{TAX})$ & 0.314878 & 0.125872 & 2.501573 & $0.0080 * *$ \\
\hline$\Delta(\mathrm{MS}(3))$ & 0.904916 & 0.870846 & -1.039123 & 0.1890 \\
\hline$\Delta(\mathrm{OPEN})$ & 0.645529 & 0.145333 & 4.441720 & $0.0003 * *$ \\
\hline Constant & 0.208862 & 0.133406 & 1.565612 & 0.1349 \\
\hline
\end{tabular}
** \& * indicate statistically significant at the 0.05 and 0.1 level

Source: Researcher's Compilation from E-view-9 (2021)

The lagged error correction mechanism ECM (t-1) revealed an inverse sign and statistically significant at 5\% level. This finding implies that the short-run and long-run dynamic was linked at an adjustment speed of $77.5 \%$ annually. The position of this in that the disequilibrium that occurred from short-run to long-run was corrected at an annual rate of $77.5 \%$. This finding was in-line with the study of Odior (2013) that showed that there was presence of disequilibrium from short-run to long-run on selected macroeconomic and manufacturing sector output.

The absolute coefficient of interest rate was $12.2 \%$ which was also negative and non-significant. This means that increase in interest rate had zero effect on manufacturing sector output. The negative sign of the interest rate was in consonance with a priori expectation. In the case of interest rate, its economic implication is that increase in lending rates did not proportionately reduce productivity in the sector by $12.2 \%$, but rather by other macroeconomic factors that directly influence interest rate. The non-significance nature of this finding could be attributed to many factors. First developing countries are characterized with poor financial system, hence, the requires capital to stimulate growth are not sufficiently provided by these available financial institutions. Therefore, whether interest rate increases or decreases does not influence the demand for loan by manufacturing sector which in turn has no influence on productivity. Given this, Falade, Aladejana and Oluwalana (2018) remark that lack of sufficient funds by local financial markets is responsible for decline in sectoral contribution to gross domestic product and argue further that meaningful development in every sector of the economy require external aids. Charles (2012) supported the above claims also and discloses that the demand for funds depends on the opportunities available for using borrowed funds efficiently and profitably. That is, increase in profit received from the usage of funds, increases the demand for funds. This finding was also in line with the study of Erinma (2016) and Tomola et al. (2012) that discovered that interest rate in Nigeria has a negative effect on the contribution to the manufacturing sector as well as on the average capacity utilization of the Nigeria manufacturing sector.

The coefficient of real exchange rate (14.9\%) was positive and significant at $10 \%$ level with a $p$-value less than $10 \%$ conventional level. This inference that real exchange rate had direct effect on manufacturing sector output, provided that other identified variables in the model are held constant. In the case of real exchange rate, it implies that appreciation of naira compare with a dollar in term of good and services between the two countries improved manufacturing performance. This sign obtained from the estimated coefficient was in-line with the study of Tams, et al (2018) that confirmed a non-significant and direct relationship between exchange rate and manufacturing industry output. Also, it was contrary with the study of Peace (2019), Caleb, Bamisele, Niyi-Oyebanji and Damilola (2019) and Charles (2012) who discovered in their separate studies that exchange rates has a negative significant relationship, on the manufacturing industry growth in Nigeria. The disparity in finding could be attributed to methodology adopted by each studies, years of study as well as the present used of real exchange rate.

The coefficient of tax rate was positive and significance at $5 \%$ significance level judging from the $p$-value $(0.0080)$ that was less than 0.5 . The implication of this is that gradual increase in levy on consumption tax from the stage in which raw material is transformed into finished goods to other stages where value is added to the point of sale directly influence on manufacturing performance. It has been argued and approved that revenue generation through collection of different taxes serve as a source of revenue generation for government. Thus, established the fact that increase in government revenue through collection of tax especially VAT increase provision of infrastructural facilities for industrial and manufacturing growth. This finding was in agreement with the a priori expectation.

The coefficient result of money supply was $90.5 \%$ with a $p$-value $(0.1890)$ greater than 0.05 and 0.1 significance level. This implies that money supply was not significant but the signed obtained was in-line with the $a$ priori expectation formulated to the study. The non-significant nature of this finding could be attributed to low financial based in developing countries like Nigeria. For instance, Falade et al. (2020) reveal that Nigeria's financial system is characterized with local financial markets that lack sufficient funds to stimulate economic growth and development. In 
view of this, Babatunde et al., (2011) confirmed that the Nigerian financial sector that is part of financial development is characterized by a shortage of funds, therefore, reduce their credit to the private sector. Also, study carried out by Ogunleye and Saliu (2013) arrived at the same conclusion.

The result indicated that a positive relationship existed between trade openness and manufacturing performance at $5 \%$ significance level. Implying that trade openness had a direct effect and aggregate contribution of $64.6 \%$ on manufacturing sector performance over the years under review. However, the establishment of a positive influence of trade openness on manufacturing performance implies that more inflow of equipment and industrial needs boost manufacturing sector performance. Moreover, trade openness could go a long way in stimulating manufacturing performance positively when more foreign currency such as FDI, and others are directed into the sector.

\subsection{Diagnostic Checks}

\section{Adjusted R $\mathbf{R}^{2}$}

The overall value of the adjusted $\mathrm{R}^{2}$ for the model was pegged at $53.2 \%$, which implies that interest rate, real exchange rate, tax rate, money supply and trade openness explained about $53.2 \%$ systematic variation on manufacturing sector output over the observed years in the Nigeria economy; while, the remaining $46.8 \%$ variation was explained by other variables outside the model.

\begin{tabular}{|llll|}
\hline Breusch-Godfrey Serial Correlation LM Test: & \\
\hline F-statistic & 3.619629 & Prob. F(2,16) & 0.1505 \\
Obs*R-squared & 7.787747 & Prob. Chi-Square(2) & 0.2204 \\
\hline
\end{tabular}

Figure 1. Autocorrelation Test of the Model

Source: Researcher's Compilation from E-view-9 (2021)

The $p$-value of the estimated Breusch was greater than 0.05 levels. Implying that the null hypothesis of no serial correlation was accepted. Thus, confirmed that no serial correlation among the variables in the model.

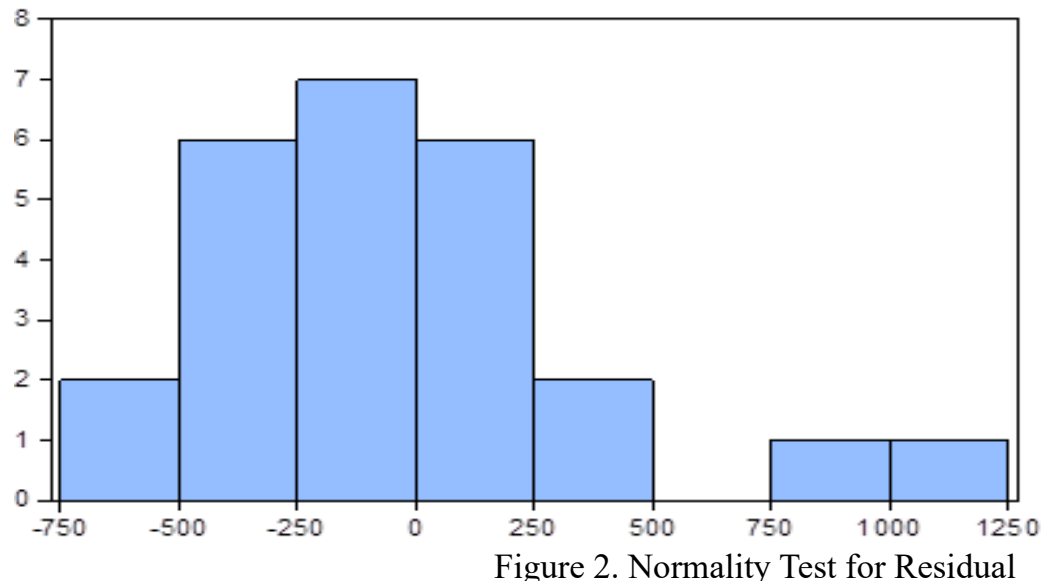

\begin{tabular}{|lc|}
\hline \multicolumn{2}{|l|}{ Series: Re siduals } \\
Sample 1995 2019 \\
Observations 25 \\
Mean & $1.36 \mathrm{e}-14$ \\
Median & -33.22770 \\
Maximum & 1028.644 \\
Minimum & -667.6411 \\
Std. Dev. & 405.2472 \\
Skewness & 0.725409 \\
Kurtosis & 3.649897 \\
& \\
Jarque-Bera & 2.632542 \\
Probability & 0.268133 \\
\hline
\end{tabular}

Figure 2 result showed that Jargue-bera $p$-value was greater than 5\%. Thus, confirmed that the residual of the model was normally distributed.

Table 6. Pairwise Granger Causality Tests

\begin{tabular}{llcll}
\hline Variable of null hypothesis & Direction & Observation & F-Statistic & Prob. \\
\hline REER does not Granger Cause MANO & & & 4.36268 & $0.0276^{* *}$ \\
MANO does not Granger Cause REER & $\leftrightarrow$ & 24 & 5.87926 & $0.0103^{* *}$ \\
TAX does not Granger Cause MANO & & & 3.99386 & $0.0357^{* *}$ \\
MANO does not Granger Cause TAX & $\leftrightarrow$ & 24 & 12.1018 & $0.0004^{* *}$ \\
TAX does not Granger Cause REER & & & 3.59493 & $0.0474^{* *}$ \\
REER does not Granger Cause TAX & $\rightarrow$ & 24 & 0.30862 & 0.7381 \\
MS(3)does not Granger Cause TAX & & & 3.25954 & $0.0607^{*}$ \\
TAX does not Granger Cause MS(3) & $\rightarrow$ & 24 & 0.78849 & 0.4689 \\
\hline * \& ** indicate statistically significant and rejection of the null hypothesis at 0.05 \& 0.1 level &
\end{tabular}

$* \& * *$ indicate statistically significant and rejection of the null hypothesis at $0.05 \& 0.1$ level

Source: Researcher's Compilation from E-view-9 (2021)

The granger test result shows that both real exchange rate and manufacturing sector output were significant at the conventional level of 0.05 . Implying that the null hypotheses of the two formulated stands were rejected. Therefore, 
confirmed that both real exchange rate and manufacturing sector granger caused each other under the years reviewed. Thus, confirmed a two-way causality or bi-directional causality between the duo. The economic implication of this is that the ability to sustain manufacturing sector performance depends on appreciation of nigeria's currency (naira) in relation to US's dollar in term of good and services. Similar finding was reached with tax rate and manufacturing sector output with the $p$-value of the duo less than 5\% and statistically significant. Implying that the duo granger caused each other. Thus, confirmed a bi-directional relationship between them. The implication of this is that increase in levy on consumption tax couple with proportional improvement in infrastructural facilities provided by government are also needed to sustain manufacturing sector performance. Furthermore, a one-way causality was established between tax rate and real exchange rate; likewise, between money supply and tax at $5 \%$ and $10 \%$ conventional level respectively.

\section{Conclusion and Policy Recommendations}

Based on the findings of this study, it was obvious that real exchange rate, tax rate, and trade openness were the significant factors that affected manufacturing sector output in Nigeria. In addition, interest rate and money supply exhibited an indirect and direct relationship with manufacturing sector output but non-significance. This study therefore, concludes that increase in consumption tax, real exchange rate and liberation of the economy were the determinants of manufacturing sector performance, while appreciation of nigeria's currency (naira) in relation to US's dollar and increase in tax rate with proportional improvement in infrastructural facilities are needed to sustain manufacturing sector performance. Hence, the following recommendations are made.

Financial institutions in the country especially the apex bank should eliminate different bench-mark of exchange rate policy by allowing the market force of demand and supply to depict the real value of naira in relative to other foreign currencies especially the US's dollar through maintaining of floating exchange rate policy. Also, the sustainability of manufacturing sector performance depends on it, therefore, the ideal of mono-economy and over-dependency on revenue from crude oil and gas must be erased in order not to depreciate the value of naira at the face of fall in price of crude oil in the international market.

Government must ensure that increase in tax rate especially that of Value Added Tax must reflect the proportion of infrastructural facilities provided. Finding established that gradual increase in levy on consumption tax directly influence manufacturing performance. This therefore, becomes necessary for government to see VAT as an area of revenue generation to provide developmental infrastructural facility for manufacturing sector. Also, the sustainability of the industry output depends on proportional improvement in infrastructural facilities and tax received by government.

Nigerian government and policy makers should formulate policies such as removing of trade barriers that would encourage more inflow of industrial need; Findings revealed that trade openness directly contributed to manufacturing sector performance. This therefore, necessitates the need for government and policy makers to create conducive environment and policies in order to increase inflows of industrial needs so as to easing the pressures on labours.

Financial institution like apex bank should put in place mechanism that would encourage more inflow of foreign currency into the financial institutions of the country in order for them to be buoyancy enough to cater for industrial needs of manufacturing sector and also embark on interest rate reforms which can reduce the wide interest rate spread between lending and deposit rate in Nigeria.

\section{References}

Achi, P. C. (2020). The impact of macroeconomic factors on development of manufacturing sector in Nigeria. Researchgate, 1-78.

Akpan, D. B., Yilkudi, D. J., \& Opiah, D. C. (2016). The impact of lending rate on the manufacturing sector in Nigeria. Central Bank of Nigeria Publication, 2(4), 34-48.

Babatunde, O., Olayinka, M., \& Okwy, P. (2011). Impact of Workers' Remittances on Financial Development in Nigeria. International Business Research, 4(4), 13-26. https://doi.org/10.5539/ibr.v4n4p218

Central Bank of Nigeria. (2019). Public Sector Statistical Bulletin. Publication of the CBN.

Charles, A. N. B. (2012). Investigating the performance of monetary policy on manufacturing sector in Nigeria. Arabian Journal of Business and Management Review, 2(1), 12-25. https://doi.org/10.12816/0002239

Ebere, E. J., \& Iorember, P. T. (2016). Commercial bank credit and manufacturing sector output in Nigeria. Journal of Economics and Sustainable Development, 7(16), 189-196.

Egbunike, C. F., \& Okerekeoti, C. C. (2018). Macroeconomic factors, firm characteristics and financial performance: A study of selected quoted manufacturing firms in Nigeria. Asian Journal of Accounting Research, 3(2), 142-168. https://doi.org/10.1108/AJAR-09-2018-0029 
Erinwa, N. (2016). Impact of rising interest rate on the performance of the Nigeria manufacturing sector. European Journal of Business and Management, 8(10), 1-10.

Falade, A. O. O. (2021). The Presence of Dutch Disease in Nigeria: The implication of rise in oil revenue. International Journal of Research and Innovation in Social Science, 3(7), 231-243.

Falade, A. O. O., Aladejana, S. A., \& Alabi, J. A. (2020). Accessibility of financial inclusion among women in Akoko Areas of Ondo State, Nigeria. SAU Journal of Management and Social Sciences, 5(2), 66-77.

Falade, A. O. O., Aladejana, S. A., \& Oluwalana, F. A. (2018). External debt in Nigeria: How sustainable using Heavily Indebted Poor Countries (HIPC) indicators? AAU Anal of Accounting, Educational and Social Research, 5(2), 34-43.

Manufacturers Association of Nigeria. (2018). Manufacturing sector experience.

Nwanne, T. F. I. (2015). Implications of government capital expenditure on the manufacturing sector in Nigeria. European Journal of Accounting, Auditing and Finance Research, 3(10), 19-33.

Obamuyi, T. M., Edun, A. T., \& Kayode, O. F. (2012). Bank lending, economic growth and the performance of the manufacturing sector in Nigeria. European Scientific Journal, 8(3), 57-78.

Odiora, E. S. (2013). Macroeconomic variables and productivity of the manufacturing sector in Nigeria. A static analysis approach. Journal of Emerging Issues in Economics, Finance and Banking, 1(5), 362-379.

Ogar, A., Nkamare, S. E., \& Effiong, C. (2014). Commercial bank credit and its contributions on manufacturing sector in Nigeria. Journal of Finance and Accounting, 5(22), 188-191.

Ogunleye, E. O., \& Saliu, M. (2013). Long-run relations between the financial institutional reforms and the Nigerian manufacturing performance (1970-2005). Journal of Economics and Sustainable Development, 4(15), 80-87.

Olayemi, S. O., \& Michael, O. (2016). Financial reforms and industrial productivity growth in Nigeria. Journal of Economics and Sustainable Development, 7(7), 64-70.

Olorunfemi, S., Tomola, M., Felix, O., \& Ogunleye, E. (2013). Manufacturing performance in Nigeria: Implication for sustainable development. Asian Economic and Financial Review, 3(9), 1195-1213.

Onakoye, A. B., Ogundajo, G. O., \& Johnson, B. S. (2017). Monetary policy and the sustainability of the manufacturing sector in Nigeria. Review of innovation and competitiveness, 3(4), 73-87. https://doi.org/10.32728/ric.2018.34/4

Peace, E. (2019). Selected macroeconomic variables and their effect on manufacturing sector Performance. B.Sc. long-essay, submitted to the Department of Economics, Adekunle Ajasin University, Akungba-Akoko.

Peter, O., Ben-Caleb, E., Bamisele, R., Niyi-Oyebanji, M., \& Damilola, E. (2019). Impact of exchange rate on the manufacturing sector in Nigeria. International Journal of Mechanical Engineering and Technology, 10(2), 1568-1583.

Rafiq, R. (2018). Manufacturing in Nigeria: Status, challenges and opportunities. Retrieved from https://www.howwemadeitinafrica.com/manufacturing-in-nigeriastatus-challenges-and-opportunities/62236/

Tams, A. O., Olokoyo, F., Okoye, L. U., \& Ejemeyovwi, J. (2018). Impact of exchange rate deregulation on manufacturing sector performance in Nigeria. International of Research in Social Science, 3(2), 24-34.

World Bank. (2016). Migration and development brief 27, migration and remittances: Recent development and Outlook, Special Topic on Global Compact on Migration. The World Bank, Washington, DC.

Zulfiqar, Z., \& Din, N. U. (2015). Inflation, interest rate and firms' performance: The evidences from the textile industry of Pakistan. International Journal of Arts and Commerce, 4(2), 12-23.

\section{Copyrights}

Copyright for this article is retained by the author(s), with first publication rights granted to the journal.

This is an open-access article distributed under the terms and conditions of the Creative Commons Attribution license which permits unrestricted use, distribution, and reproduction in any medium, provided the original work is properly cited. 